\section{Seropositivity combined with smoking is associated with increased prevalence of periodontitis in patients with rheumatoid arthritis}

An association between periodontitis and rheumatoid arthritis (RA) has been proposed based on observations of increased risk of periodontitis in patients with RA as well as the presence of antibodies to citrullinated protein antigens (ACPAs) and rheumatoid factor (RF) in serum and gingiva of patients with periodontitis. ${ }^{1-3}$ Additionally, smoking is one of the most important risk factors for both periodontitis and RA, and predispose for the development of seropositive RA. ${ }^{4-6}$ We have previously reported that smokers with RA have increased prevalence of periodontitis as compared with never smokers in the Swedish population-based case-control study EIRA (Epidemiological Investigation of Rheumatoid Arthritis). ${ }^{7}$ The objective of the current study was to further investigate the effects of smoking on the risk of periodontitis in seropositive and seronegative (ACPA/ RF) subsets of RA.

Data on periodontal status (years 2008-2012) were retrieved from the Swedish Dental Health Registry (DHR) for 2327 patients with established RA (1469/852 ACPA-positive/ACPA-negative and 1505/822 RF-positive/RF-negative, respectively) included in the EIRA study (years 1996-2009) as previously described. ${ }^{7}$ Periodontal diagnosis was based on diagnostic codes for periodontitis, peri-implantitis and increased risk of periodontitis/peri-implantitis, registered by the patients' dentists in the DHR. ${ }^{7}$ The diagnosis of RA was confirmed by the rheumatologist at the time of the recruitment into EIRA; blood samples were collected to determine ACPA/RF status. ${ }^{8}$ Detailed information on smoking status was collected by a self-administered questionnaire at the time of enrolment to EIRA. ${ }^{8}$ For the association between smoking status, seropositive/seronegative RA and periodontitis, we calculated OR with 95\% CI adjusted for age, gender, education and residential area.

In ACPA-positive RA, smoking was associated with a significantly $(\mathrm{p}<0.05)$ higher prevalence of periodontitis, mainly in current smokers $(\mathrm{OR}=1.9,95 \% \mathrm{CI} 1.5$ to 2.5$)$ (table 1$)$. The

Table 1 Association between periodontal diagnostic codes and smoking habits compared with never smokers in EIRA RA cases, in relation to ACPA status and gender*

\begin{tabular}{|c|c|c|c|c|c|}
\hline \multirow[b]{2}{*}{ Smoking habits } & & \multicolumn{2}{|c|}{ ACPA-positive RA ( $n=1469)$} & \multicolumn{2}{|c|}{ ACPA-negative RA $(n=852)$} \\
\hline & & $\begin{array}{l}\text { No with periodontitis } \\
(\%) \dagger\end{array}$ & OR $(95 \% \mathrm{Cl}) \neq$ & $\begin{array}{l}\text { No with periodontitis } \\
(\%) \dagger\end{array}$ & OR $(95 \% \mathrm{Cl}) \ddagger$ \\
\hline & All & $773(100)$ & & $458(100)$ & \\
\hline & Women & $557(100)$ & & $331(100)$ & \\
\hline & Men & $216(100)$ & & $127(100)$ & \\
\hline & Women & $156(28.0)$ & 1.0 (ref) & $115(34.7)$ & 1.0 (ref) \\
\hline & Men & $40(18.5)$ & 1.0 (ref) & $40(31.5)$ & 1.0 (ref) \\
\hline \multicolumn{6}{|l|}{ Ex-smokers } \\
\hline & All & $285(36.9)$ & $1.7(1.3$ to 2.2$) \S$ & $140(30.6)$ & $0.9(0.7$ to 1.3$)$ \\
\hline & Women & $200(35.9)$ & 1.8 (1.4 to 2.4$) \S$ & $88(26.6)$ & $1.0(0.7$ to 1.5$)$ \\
\hline & Women & $401(72.0)$ & $1.6(1.3$ to 2.1$) \S$ & $216(65.3)$ & $1.3(0.9$ to 1.7$)$ \\
\hline & Men & $176(81.5)$ & $1.9(1.2$ to 3.0$) \S$ & $87(68.5)$ & $0.8(0.5$ to 1.3$)$ \\
\hline \multicolumn{6}{|l|}{ Current smokers } \\
\hline & All & $232(30.0)$ & 1.9 (1.5 to 2.5$) \S$ & $111(24.2)$ & $1.2(0.9$ to 1.6$)$ \\
\hline & Women & $157(28.2)$ & 1.8 (1.3 to 2.4$) \S$ & $85(25.7)$ & 1.4 (0.9 to 2.0$)$ \\
\hline & Men & $75(34.7)$ & $2.9(1.6$ to 5.3$) \S$ & $26(20.5)$ & 0.7 (0.4 to 1.4$)$ \\
\hline
\end{tabular}

${ }^{*}$ The periodontal diagnostic codes include periodontitis, peri-implantitis and increased risk for periodontitis/peri-implantitis.

†Number (\%) of ACPA-positive or ACPA-negative RA cases with periodontal diagnostic codes.

$\ddagger 0 R s$, with a $95 \% \mathrm{Cl}$, were adjusted for age, gender, education and residential area.

§p Value $<0.05$ for association between periodontal diagnostic codes and smoking habits as compared with never smokers among ACPA-positive and ACPA-negative RA cases. ACPA, anticitrullinated protein antibody; EIRA, Epidemiological Investigation of Rheumatoid Arthritis; RA, rheumatoid arthritis; ref, reference group. 
Table 2 Association between periodontal diagnostic codes and smoking habits compared with never smokers in EIRA RA cases, in relation to double seropositive or negative antibody status and gender*

\begin{tabular}{|c|c|c|c|c|c|}
\hline \multirow[b]{2}{*}{ Smoking habits } & & \multicolumn{2}{|c|}{ ACPA-positive and RF-positive RA ( $n=1261)$} & \multicolumn{2}{|c|}{ ACPA-negative and RF-negative RA ( $n=616)$} \\
\hline & & $\begin{array}{l}\text { No with periodontitis } \\
(\%) \dagger\end{array}$ & OR $(95 \% \mathrm{Cl}) \ddagger$ & $\begin{array}{l}\text { No with periodontitis } \\
(\%) \dagger\end{array}$ & OR $(95 \% \mathrm{Cl}) \ddagger$ \\
\hline \multicolumn{6}{|l|}{ Total } \\
\hline & All & $667(100)$ & & $328(100)$ & \\
\hline & Women & $479(100)$ & & $234(100)$ & \\
\hline & Men & $188(100)$ & & $94(100)$ & \\
\hline \multicolumn{6}{|l|}{ Never smokers } \\
\hline & All & $162(24.3)$ & 1.0 (ref) & $122(37.2)$ & 1.0 (ref) \\
\hline & Women & $130(27.1)$ & 1.0 (ref) & $90(38.5)$ & 1.0 (ref) \\
\hline & Men & $32(17.0)$ & 1.0 (ref) & $32(34.0)$ & 1.0 (ref) \\
\hline \multicolumn{6}{|l|}{ Ex-smokers } \\
\hline & All & $254(38.1)$ & $1.8(1.4$ to 2.3$) \S$ & $94(28.7)$ & $0.8(0.6$ to 1.1$)$ \\
\hline & Women & $178(37.2)$ & $1.9(1.4$ to 2.5$) \S$ & $53(22.6)$ & $0.8(0.5$ to 1.2$)$ \\
\hline & Men & $76(40.4)$ & 1.9 (1.1 to 3.4$) \S$ & $41(43.6)$ & $0.7(0.4$ to 1.3$)$ \\
\hline \multicolumn{6}{|l|}{ Ever smokers } \\
\hline & All & $505(75.7)$ & $1.7(1.4$ to 2.1$) \S$ & $206(62.8)$ & $1.0(0.7$ to 1.2$)$ \\
\hline & Women & $349(72.9)$ & 1.7 (1.3 to 2.2$) \S$ & $144(61.5)$ & 1.1 (0.8 to 1.5 ) \\
\hline & Men & $156(83.0)$ & $2.0(1.2$ to 3.3$) \S$ & $62(66.0)$ & 0.7 (0.4 to 1.1$)$ \\
\hline \multicolumn{6}{|l|}{ Current smokers } \\
\hline & All & $200(30.0)$ & 2.0 (1.5 to 2.7$) \S$ & $76(23.2)$ & $1.0(0.7$ to 1.5$)$ \\
\hline & Women & $133(27.8)$ & 1.8 (1.3 to 2.5$) \S$ & $61(26.1)$ & 1.3 (0.8 to 1.9$)$ \\
\hline & Men & $67(35.6)$ & $3.3(1.8$ to 6.2$) \S$ & $15(16.0)$ & 0.5 (0.2 to 1.1$)$ \\
\hline
\end{tabular}

*The periodontal diagnostic codes include periodontitis, peri-implantitis and increased risk for periodontitis/peri-implantitis.

tNumber (\%) of ACPA-positive and RF-positive or ACPA-negative and RF-negative RA cases with periodontal diagnostic codes.

$\neq 0 R s$, with a $95 \% \mathrm{Cl}$, were adjusted for age, gender, education and residential area.

$\S p<0.05$ for association between periodontal diagnostic codes and smoking habits as compared to never smokers among ACPA-positive and RF-positive or ACPA-negative and

RF-negative RA cases.

ACPA, anticitrullinated protein antibody; EIRA, Epidemiological Investigation of Rheumatoid Arthritis; RA, rheumatoid arthritis; ref, reference group; RF, rheumatoid factor.

highest prevalence of periodontitis, with almost a threefold increased risk, was observed among current smoking ACPA-positive men $(\mathrm{OR}=2.9$, 95\% CI 1.6 to 5.3). For ACPA-negative RA, no convincing association between smoking and periodontitis was observed (table 1$)$. Similar associations $(\mathrm{p}<0.05)$ were observed in analysis based on RF status (RF-positive current smokers; $\mathrm{OR}=1.9,95 \% \mathrm{CI} 1.5$ to 2.5 ) with the highest $\mathrm{OR}$ observed in RF-positive current smoking men $(\mathrm{OR}=2.9,95 \% \mathrm{CI}$ 1.6 to 5.2 ) (table not shown).

Interestingly, the OR for periodontitis increased even further among patients double positive for ACPA and RF antibodies, with OR of 3.3 (95\% CI 1.8 to 6.2) observed in current smoking men compared with never smokers (table 2).

We herein demonstrate that the previously observed association between smoking and periodontitis in $\mathrm{RA}^{7}$ is confined to patients with seropositive RA, especially those with both ACPA and RF antibodies. One reason for the increased risk of periodontitis in seropositive RA may be due to enhanced ACPA and/ or RF titres in smokers since smoking is reported to be associated with increased risk for seropositive RA and higher titres of $\mathrm{ACPA} / \mathrm{RF}$ in RA, and furthermore, periodontitis has been associated with increased levels of $\mathrm{ACPA} / \mathrm{RF}$ in patients with RA. ${ }^{145910}$ Smoking did not, however, significantly increase the prevalence of periodontitis in ACPA-negative/RF-negative RA, suggesting different pathophysiological mechanisms depending on autoantibody status in patients with RA. Our results are in line with previous findings that seropositive and seronegative RA represent distinct disease subsets differing in several aspects, including the association between seropositive RA with specific genetic and environmental risk factors such as human leukocyte antigen (HLA)-shared epitope and smoking. ${ }^{45}$ In summary, the highest risk of periodontitis in patients with established RA was observed among seropositive current smokers, especially those double positive for ACPA and RF antibodies, a finding that warrants awareness by clinicians and their patients as well as further investigations on the mechanisms behind this association.

Kaja Eriksson, ${ }^{1}$ Lena Nise, ${ }^{2}$ Lars Alfredsson, ${ }^{2,3}$

Anca Irinel Catrina, ${ }^{4}$ Johan Askling, ${ }^{4,5}$ Karin Lundberg, ${ }^{4}$ Lars Klareskog, ${ }^{4}$ Tülay Yucel-Lindberg ${ }^{1}$

${ }^{1}$ Division of Periodontology, Department of Dental Medicine, Karolinska Institutet, Stockholm, Sweden

${ }^{2}$ Unit of Cardiovascular Epidemiology, Institute of Environmental Medicine, Karolinska Institutet, Stockholm, Sweden

${ }^{3}$ Centre of Environmental and Occupational Medicine, Stockholm County Council, Stockholm, Sweden

${ }^{4}$ Rheumatology Unit, Department of Medicine, Karolinska University Hospital, Stockholm, Sweden

${ }^{5}$ Clinical Epidemiology Unit, Department of Medicine, Karolinska Institutet, Stockholm, Sweden

Correspondence to Dr Tülay Yucel-Lindberg and Dr Kaja Eriksson, Division of Periodontology, Department of Dental Medicine, Karolinska Institutet, Box 4064, SE-141 04 Huddinge, Sweden; tulay.lindberg@ki.se, Kaja.eriksson@ki.se

Acknowledgements The authors thank all the EIRA participants, clinicians and research nurses and the investigators and founders of the EIRA study. We also thank Lena Israelsson and Hiba Mahdi for analysing the presence of anti-CCP2 antibodies in EIRA. 
Contributors TY-L, LK, LA, KL, JA and AIC conceived and designed the study. $T Y-L, L N$ and KE acquired and analysed the data. The statistical analysis was conducted by LN. Interpretation of data was made by TY-L, KE, LA, LK, KL, JA and AIC. KE and TY-L drafted the manuscript. All authors revised the article for important intellectual content and approved the final version for publication.

Funding This work was supported by the collaborative European Union's FP7 Research Projects-Gums \& Joints (grant agreement no FP7-HEALTH-2010-261460) and TRIGGER (grant agreement no FP7HEALTH-2013-306029), the Stockholm County Council (SOF and ALF), the Swedish Research Council, the Swedish Dental Society, the Swedish Rheumatic Foundation and Karolinska Institutet.

Competing interests None declared.

Patient consent Obtained.

Ethics approval Regional Ethics Board in Stockholm approved the study design and written consent was obtained from all subjects.

Provenance and peer review Not commissioned; externally peer reviewed.

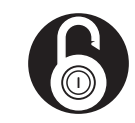

\section{OPEN ACCESS}

Open access This is an open access article distributed in accordance with the Creative Commons Attribution Non Commercial (CC BY-NC 4.0) license, which permits others to distribute, remix, adapt, build upon this work non-commercially, and license their derivative works on different terms, provided the original work is properly cited and the use is non-commercial. See: http://creativecommons.org/ licenses/by-nc/4.0/

(c) Article author(s) (or their employer(s) unless otherwise stated in the text of the article) 2018. All rights reserved. No commercial use is permitted unless otherwise expressly granted.

\section{A) Check for updates}

To cite Eriksson K, Nise L, Alfredsson L, et al. Ann Rheum Dis 2018;77:1236-1238.

Received 17 July 2017

Revised 5 September 2017

Accepted 8 September 2017

Published Online First 6 October 2017

Ann Rheum Dis 2018;77:1236-1238. doi:10.1136/annrheumdis-2017-212091

\section{REFERENCES}

1 Mikuls TR, Payne JB, Yu F, et al. Periodontitis and Porphyromonas gingivalis in patients with rheumatoid arthritis. Arthritis Rheumatol 2014;66:1090-100.

2 Lappin DF, Apatzidou D, Quirke AM, et al. Influence of periodontal disease, Porphyromonas gingivalis and cigarette smoking on systemic anti-citrullinated peptide antibody titres. J Clin Periodontol 2013;40:907-15.

3 Gargiulo AV, Robinson J, Toto PD, et al. Identification of rheumatoid factor in periodontal disease. J Periodontol 1982;53:568-77.

4 Gerlag DM, Norris JM, Tak PP. Towards prevention of autoantibody-positive rheumatoid arthritis: from lifestyle modification to preventive treatment. Rheumatology 2016;55:607-14.

5 Malmström V, Catrina Al, Klareskog L. The immunopathogenesis of seropositive rheumatoid arthritis: from triggering to targeting. Nat Rev Immunol 2017;17:60-75.

6 Tomar SL, Asma S. Smoking-attributable periodontitis in the United States: findings from NHANES III. National Health and Nutrition Examination Survey. J Periodontol 2000;71:743-51.

7 Eriksson K, Nise L, Kats A, et al. Prevalence of periodontitis in patients with established rheumatoid arthritis: a Swedish population based case-control study. PLoS One 2016;11:e0155956.

8 Klareskog L, Stolt P, Lundberg K, et al. A new model for an etiology of rheumatoid arthritis: smoking may trigger HLA-DR (shared epitope)-restricted immune reactions to autoantigens modified by citrullination. Arthritis Rheum 2006;54:38-46.

9 Mikuls TR, Hughes LB, Westfall AO, et al. Cigarette smoking, disease severity and autoantibody expression in African Americans with recent-onset rheumatoid arthritis. Ann Rheum Dis 2008:67:1529-34.

10 Gonzalez SM, Payne JB, Yu F, et al. Alveolar bone loss is associated with circulating anti-citrullinated protein antibody (ACPA) in patients with rheumatoid arthritis. J Periodontol 2015;86:222-31. 